\title{
Female entrepreneurs in transition economies: insights from Albania, Macedonia and Kosovo
}

\author{
Veland Ramadani* \\ Faculty of Business and Economics, \\ South-East European University, \\ 1200 Tetovo, Macedonia, \\ Email: v.ramadani@seeu.edu.mk \\ *Corresponding author
}

\section{Robert D. Hisrich}

Garvin Professor of Global Entrepreneurship, Thunderbird School of Global Management, Glendale, AZ 85306, USA

Email: robert.hisrich@thunderbird.edu

\section{Shqipe Gërguri-Rashiti}

College of Business Administration, American University of Middle East, Block 3, Al-Eqaila, Kuwait

Email: shqipe.gerguri-rashiti@aum.edu.kw

\begin{abstract}
Female entrepreneurship is a growing trend in transition economies. This article focuses on female entrepreneurs in Albania, Macedonia and Kosovo (hereinafter ALMAKOS) and provides an understanding of current motives, problems and perspectives of female entrepreneurs in this region. Surveys were conducted during the period of January-March 2014 (Macedonia) and May-June 2014 (Albania and Kosovo), to complement secondary sources. The results are reported in terms of the female entrepreneur's personal characteristics, motives for starting a business, the characteristics of their business and operations, the size of the business they run, revenues, their family status, management problems in starting or maintaining their businesses and their self-perceived required competences.
\end{abstract}

Keywords: entrepreneurs; female entrepreneurs; motives; problems; management capabilities; Albania; Macedonia; Kosovo.

Reference to this paper should be made as follows: Ramadani, V., Hisrich, R.D. and Gërguri-Rashiti, S. (2015) 'Female entrepreneurs in transition economies: insights from Albania, Macedonia and Kosovo', World Review of Entrepreneurship, Management and Sustainable Development, Vol. 11, No. 4, pp.391-413.

Biographical notes: Veland Ramadani is an Assistant Professor at Faculty of Business and Economics, South-East European University, Republic of Macedonia, where he teaches both undergraduate and postgraduate courses in entrepreneurship and small business management. His research interests 
include entrepreneurship, small business management and venture capital investments. He authored or co-authored over 40 research articles and 11 books. Also, he serves as a member of editorial and reviewer board of several international journals. He was engaged by the President of Republic of Macedonia as a member of experts' committee to analyse the economical, technological and juridical conditions for establishing techno-parks in the Republic of Macedonia. He has also delivered different trainings to the heads of departments in the Ministry of Economy of Macedonia.

Robert D. Hisrich is the Garvin Professor of Global Entrepreneurship and Director of the Center for Global Entrepreneurship at Thunderbird School of Global Management, one of the world's leading schools of global business. A world-renowned expert and author on entrepreneurship, He himself is a global entrepreneur who has been involved in the founding of more than a dozen companies including H\&B Associates, a marketing and management consulting firm. He has authored or co-authored 38 books and over 350 articles on entrepreneurship, international business management and venture capital. $\mathrm{He}$ has served on the editorial boards of The Journal of Business Venturing, Entrepreneurship Theory and Practice, Journal of Small Business Management and Journal of International Business and Entrepreneurship.

Shqipe Gërguri-Rashiti is an Assistant Professor and teaches mostly undergraduate courses in management and information systems at College of Business Administration, American University of Middle-East (Kuwait). Previously, she has taught at South East European University (Macedonia). Her research interests include management, strategic management, management information systems, etc. She authored around 20 research articles. Besides being a Lecturer she has been also involved in managing UNDP projects within the South-East European University, Macedonia.

\section{Introduction}

Female entrepreneurs and their role in the economy are of interest to researchers, policymakers and the general population (Hisrich et al., 2006; Hisrich, 1986, 1984; Hisrich and Fan, 1991; Byrne and Fayolle, 2013; Welter and Smallbone, 2010; Henry and Johnston, 2007; Kariv, 2013; Welter et al., 2004; Ramadani et al., 2013; Minniti et al., 2005). There are several reasons for this interest and the need for research in this area:

a male entrepreneurs have been recognised as an important source of economic growth, considering that they create new jobs for themselves and others, provide different solutions to management, organisation and business problems and obstacles as well as the exploitation of new business opportunities

b male entrepreneurship was traditionally neglected both in society in general and in the social sciences, considering that mainstream research, policies and programs tend to be 'men streamed' (Baker et al., 1997; OECD, 2004).

Female entrepreneurs are growing in numbers as is their importance in society. While this is true around the world, it is especially apparent in transitional economies where the transition process has resulted in reflective and dramatic economic, political and social changes (Aidis et al., 2007; Ramadani et al., 2013). In the past, entrepreneurship was 
considered to be a male-dominated sector (Brush, 1992; Berg, 1997). From research conducted in 41 countries during 2003, it was found that men were almost twice as engaged in starting a new business as women; the TEA (the percentage of adults, who attempt to start a business or already are owners of small businesses set up earlier than 42 months) of females was $7 \%$, while that of males was $12 \%$ (Brush et al., 2006). The Global Entrepreneurship Monitor (2004) reported that women represented more than one-third of all the individuals involved in entrepreneurial activity in some countries in transition: Bulgaria, 36\%; Czech Republic, 27\%; Hungary, 31.5\%; Latvia, 35\%; Lithuania, 43.3\%; Poland, 39\%, Romania, 26\%; Bosnia and Herzegovina, 26\%, Serbia, 26\% and Macedonia, 18\% (Sabarwal and Terrell, 2008; Aidis et al., 2007; Aidis, 2003; Dombrovsky and Ieva, 2005).

With respect to transitional economies, as Kitching and Woldie (2004) noted, there are several questions and concerns raised about the position of female entrepreneurs, such as: have economic and political developments in recent years given women a greater opportunity to start their own business? What type of business are they in? What access do they have to financial and other resources? Do they face similar problems as their male counterparts? Are women subject to discrimination and harassment? Are their issues of concern similar to those of businesswomen elsewhere or are their experiences affected more by local social and economic conditions or traditional cultural norms? These questions and concerns are looked at in this article.

Female-owned enterprises are of special importance for a variety of reasons (Welter et al., 2004; OECD, 2004). First, female entrepreneurs create jobs for themselves and others. The creation of private firms by women allows them to capitalise on their experience, acquired skills and training and helps reduce the effect of discrimination against women in the labour market. Second, the establishment of private enterprises as an alternative to unemployment will give women the opportunity to balance work and family responsibilities, while improving family welfare and social cohesion. This is one of the real challenges of female entrepreneurs. Third, establishment of small enterprises owned by women can help in increasing women's autonomy and provide them the opportunity to have a more active and representative role in the country's economic and political life. Fourth, female-owned businesses can assist in fighting the trafficking of women which is a great concern in many transition countries. Fifth, female entrepreneurs can serve as role models for younger generations indicating new opportunities for employment. Finally, the development of female entrepreneurship could result in a more successful and fast transition process by the improvement of innovative capacities and private sector development.

The purpose of this article is to present our findings about female entrepreneurs in Albania, Macedonia and Kosovo (hereinafter ALMAKOS). An OECD report (2004, p.13) stated that "The scarce availability of reliable and valid data continues to be one of the key obstacles to understanding the challenges specific to women's entrepreneurship... Sex-disaggregated statistics and sex-based policy analyses have become more widespread in recent years". This same situation occurs in the ALMAKOS region as well as there is a lack of official data with respect to female entrepreneurs, types of businesses run by them, their contribution to employment and gross domestic product. Females in 2011 were $44.7 \%$ of the total workforce in Macedonia (State Statistical Office of Republic of Macedonia, 2012), 38\% in Albania and around 30\% in Kosovo (Hontz and Rotanu, 2010). Regarding the participation of women in the total workforce of the countries from the region, there is evidence of approximately the same 
situation, where in Serbia, women participation in the workforce was $41 \%$, in Montenegro, $45 \%$ in Croatia, $46 \%$ in Slovenia, $47 \%$ in Bulgaria and $46 \%$ in Romania. In Bosnia and Herzegovina, the participation of women in the workforce is lower $-34 \%$ (Hontz and Rotanu, 2010).

In order to gain a better picture of the current situation and the problems and perspectives of female entrepreneurs in the ALMAKOS region, a survey of 24 female entrepreneurs in Albania, 32 in Macedonia and 18 in Kosovo was conducted during the period of January-March 2014 (Macedonia) and May-June 2014 (Albania and Kosovo). The primary objective of this research is to discover and determine the problems and obstacles experienced by female entrepreneurs, as well as the reasons that motivate them to opt for a career in the field of entrepreneurship.

This article is divided into three sections. Following the introduction, the characteristics of female entrepreneurs are discussed. In the third section, introductory remarks about Albania, Macedonia and Kosovo are presented followed by a discussion of the characteristics of female entrepreneurs operating in these three countries. The article closes with conclusions and recommendations for policy makers, practitioners and future research.

\section{Profile of female entrepreneurs}

\subsection{Primary characteristics of female entrepreneurs}

The profile of female entrepreneurs in each of the countries is presented in terms of: age, marital status, education, career, past experience, ethnic identity, work-family clashes and reasons for starting a business.

Following the literature on female entrepreneurs such as Hisrich and Brush (1986), the general characteristics are:

1 the female entrepreneur in most cases is the first child of a middle-class family in which the father is self-employed, whose husband is employed in his profession and the family has two children aged between 12 and 16 years

$270 \%$ of female entrepreneurs have finished formal education, which often plays an important role in solving the problems that arise in business

3 female entrepreneurs typically have work experience in the service sector (teachers, mid-level manager or secretary)

4 female entrepreneurs are individualistic, creative, enthusiastic, initiative and flexible in dealing with problems in managing the business such as recruiting and firing workers, contacts with creditors, meetings with vendors and payment of bills

5 the motives for starting a business for female entrepreneurs include: independence, job satisfaction, success, opportunities, status/image, money, power and economic needs and career

6 in order for female entrepreneurs to deal with problems and issues that occur during managing their business they need some managerial skills such as managing finances, dealing with people, marketing, creating ideas, planning and organising. 


\subsection{Age}

According to a survey of 402 female entrepreneurs, the largest number of female entrepreneurs are between the ages of 30 to 40 . In Poland, female entrepreneurs were from 35 to 50 years old, in Canada from 31 to 45 years, in Asia from 30 to 40 years, in the US from 36 to 55 years, etc. (Taylor and Newcomer, 2005). The age of female entrepreneurs in Ukraine varies being from 19 to 61 , with $42 \%$, being in their 30 s and $19 \%$ are under 30 years of age (Hisrich et al., 2006). The age of female entrepreneurs when they have established their enterprises, according to a survey conducted in the European Union in 2004, over $70 \%$ of women have established their enterprises before the age of $35,15 \%$ have started their businesses at the age of 36 to 40 years old and $15 \%$ after the age of 40 (Eurochambres, 2004).

\subsection{Education}

Taylor and Newcomer (2005) found that the majority of female entrepreneurs have graduated from university, with many finishing their masters or doctorate degree. As indicated in Figure 1, specifically in this study, 20\% had secondary school education, $35 \%$ university graduates, $10 \%$ two years of university studies, $25 \%$ a master's degree and $10 \%$ a doctorate degree in different fields (the majority in the field of business and economics).

Figure 1 The level of education of female entrepreneurs

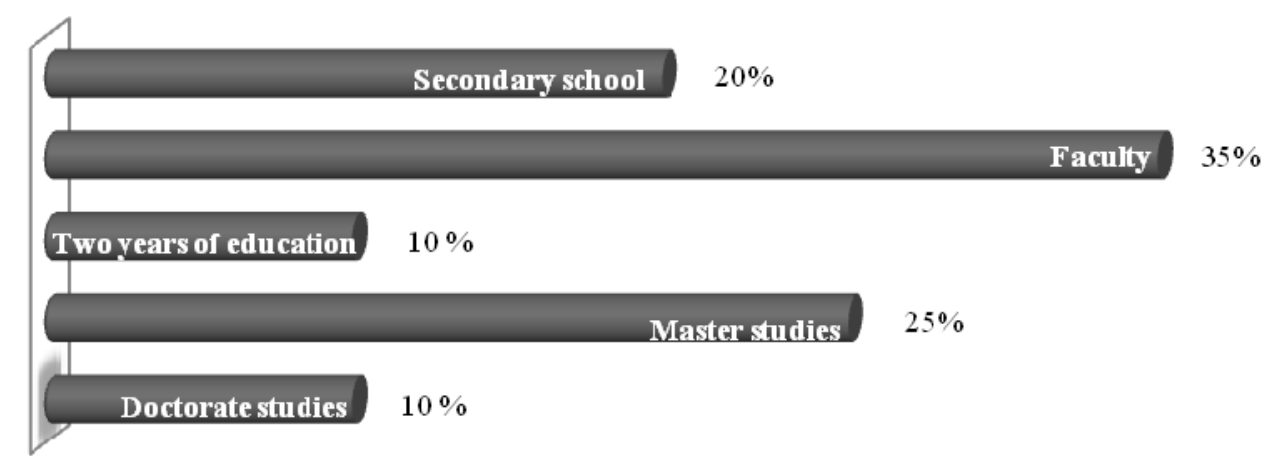

Source: Taylor and Newcomer (2005, p.21)

According to Hisrich et al. (2006), the vast majority of Ukrainian female entrepreneurs had post-secondary education; 35\% finished technical training/college; $41 \%$ completed bachelor's degrees and $18 \%$ completed graduate studies. The most frequently mentioned university majors were: teaching (13\%), engineering (10\%) and business-related fields $(8 \%)$. Most of the women's parents did not have university degrees $(66 \%$ of mothers did not and $60 \%$ of fathers did not) and $29 \%$ did not have a single parent who had more than a high school education.

\subsection{Motives to start own business}

Considering the overall motives to start a business, researchers have not found any substantial differences between countries or between men and women (Carter and 
Marlow, 2007; Bennett and Dann, 2000; Jones 2000; Hisrich and Ozturk, 1999; Maysami and Goby, 1999). Dana (1997) noted that motives to start one's own businesses are focused on three things: the self (high need for achievement, innovativeness and ability to take calculated risks); the ethno-cultural milieu (culture, thrift, frugality, asceticism and ethnic resources) and the host society (stratification, social blockage, government assistance and occupational clustering). Walker and Brown (2004) found that financial (profit and wealth creation) and non-financial (being one's own boss, having free time for personal activities, the flexibility to structure the business according to the entrepreneur's values and objectives) factors motivate female entrepreneurs. In a survey conducted in Europe, the first ranged motive of female entrepreneurs is to have control and freedom in the decision-making process ( $47 \%$ of the surveyed respondents), followed by realisation of profits and wealth creation (45\%). Other motives frequently mentioned included: self-realisation, combining family and business life and the inability to find a job [Eurochambres, (2004), p.12].

Some authors (Buttner and Moore, 1997; Walker and Brown, 2004; Hughes, 2005) divided these motives in push and pull categories, where pull motives are related with a strong desire to be self-employed based on reasons with positive connotations, such as challenge, positive work environment, independence and flexibility, while push motives are based on reasons with negative connotations, such as losing a job, limited work opportunities, lack of positive work environment and independence.

\subsection{Hours dedicated to the business}

Female entrepreneurs generally are engaged in their businesses more than 48 hours a week. Research shows that $62 \%$ of them have this engagement in their business during the week, while $25 \%$ dedicate themselves between 40 and 48 hours a week. Only $13 \%$ devote less than 40 hours per week to their business (Figure 2).

Figure 2 Hours dedicated to the business

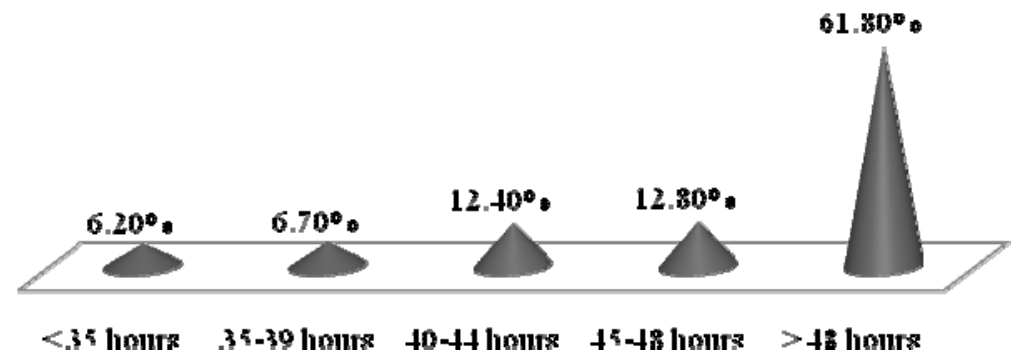

Source: Eurochambres (2004, p.11)

A small group of women (7\%) spent less than 35 hours per week in the business with the majority being from Germany, Hungary, Ireland, Italy and Luxembourg (Eurochambres, 2004).

\subsection{Business sectors}

Female entrepreneurs are increasingly participating and playing a big role in the structure of the labour force, especially in the establishment of new businesses. While they 
establish various innovative businesses (private post offices), typically they are in services (travel agencies and textile shops). Innovations in these businesses are oriented toward providing new services or upgrading the existing ones. Different research findings indicate that female entrepreneurs establish their businesses mainly in the following sectors: retail, consulting, educational services and public relations (Franco and Winqvist, 2002; Duchénaut, 1997; Reynolds and White, 1997; Hisrich and Brush, 1986). Aidis et al. (2007) found that in Lithuania, female entrepreneurs mainly operate in these sectors: retail/wholesaling (37\%), services (37\%), manufacturing (22\%) and other sectors (4\%). The research conducted by Hisrich and Brush (1986) found that $90 \%$ of businesses founded by female entrepreneurs are oriented toward services, $7 \%$ in production and 3\% in finance. Recent trends indicate that female entrepreneurs are penetrating sectors which traditionally were dominated by men, such as construction, manufacturing and high technology-based sectors (Carter and Marlow, 2007).

\subsection{Barriers}

With the continuous growth of self-employed women being a social and economic phenomenon, the prejudices about the role of women in business should be changed (Shuklev and Ramadani, 2012). Research studies have elaborated some of the barriers faced by female entrepreneurs in setting up their businesses. A study done by Gobagoba and Littrell (2003) found that female entrepreneurs faced a variety of barriers: lack of management skills, business skills, cash flow, technical skills and the ability to recruit qualified staff. In addition, the authors found that women entrepreneurs have limited access to appropriate technology.

According to Still (2005), barriers or problems that women face in starting a business are divided into three groups. The first group of barriers has to do with women who are motivated by push factors. This group of barriers include: creating confidence necessary to start business; finding the proper sources for help and advice; providing access to financial resources; lack of mentors and advisors for individual owners; problems of the isolated feelings/adaptation to change from employed to being self-employed; accepting the offers provided by suppliers, other businesses and clients; difficulties of managing both family and business affairs; low entrepreneurial spirit; coping with the risk; and access to business networks. The second group of barriers has to do with women who are motivated by pull factors. Barriers in this category include: lack of financing; access to risk-capital, capital market, real networks and business consultants; lack of ability to establish management control and create a strong management team; and access to mentors, knowledge and information necessary for business growth. The third group of barriers occurs for younger women who start their own businesses: discrimination in terms of age by consumers, government institutions and agencies; not being accepted by other colleagues-entrepreneurs and other business contacts; insufficient support from family and friends; and lack of a proper advice.

Another way to categorise the female entrepreneurs' barriers and problems is 'problems before starting the business' and 'problems during business running' [Hisrich and Brush (1986), p.16]. These problems are: lack of training, access to credits, lack of guidance and counselling, weak negotiating position and lack of experience in financial planning. Depending on when these problems occur, before or during doing business, their weight and importance changes as well as indicated in Table 1. 
Table 1 Female entrepreneurs' barriers and problems

\begin{tabular}{lccc}
\hline $\begin{array}{l}\text { Problems before the starting the } \\
\text { business }\end{array}$ & $\%$ & Problems during business running & $\%$ \\
\hline Lack of training & $30 \%$ & Lack of experience in financial & $18 \%$ \\
planning & Lack of guidance and counselling & $15 \%$ \\
Access to credits & $28 \%$ & Weak negotiating position & $13 \%$ \\
Lack of guidance and counselling & $21 \%$ & Access to credits & $11 \%$ \\
$\begin{array}{l}\text { Weak negotiating position } \\
\text { Lack of experience in financial }\end{array}$ & $21 \%$ & Lack of training & $11 \%$ \\
planning & $20 \%$ & & \\
\hline
\end{tabular}

Source: Hisrich and Brush (1986, p.16)

\subsection{Factors that drive the success}

An important issue in business is reflected in the question: what drives the success? Some of the factors that affect the success of female entrepreneurs are different than those for males. According to Box et al. (1995), there are four factors which have a positive relationship with the business success of female entrepreneurs: previous experience as a member of an entrepreneurial management team, number of previous starts, entrepreneur's age and scanning intensity. Hisrich et al. (1997) enumerate the following factors for success: level of education, years of experience, business skills, personal goals and strategy to assess the performance of female entrepreneurs. Fielden and Davidson (2005) emphasise that the success of women in business depends on two groups of factors. The first group consists of 'push' factors, while the second group are 'pull' factors. Each group of factors are presented in Table 2. 'Push' factors put pressure on women to forgo current work. 'Pull' factors are those factors that attract women to entrepreneurship and influence their decision to establish their own business (Hughes, 2003; Baughn et al., 2006).

Table 2 Factors that drive the success of female entrepreneurs

\begin{tabular}{lc}
\hline 'Push' factors & 'Pull'factors \\
\hline Lack of control & Control \\
Lack of independence & Independence \\
Lack of flexibility & Flexibility \\
Dissatisfaction from work & Being the owner \\
Unforeseen problems and barriers & Financial independence \\
White or black & 'Create the difference' \\
Lack of challenge & Focus on quality \\
Family influence & Realisation of personal ambitions \\
Unserious acceptance by others & Self-determination \\
\hline
\end{tabular}

Source: Fielden and Davidson (2005, p.266) 
Table 2 Factors that drive the success of female entrepreneurs (continued)

\begin{tabular}{lc}
\hline 'Push' factors & 'Pull' factors \\
\hline Lack of opportunities & Impact on strategy \\
Lack of attention by the owner & Realisation of personal growth \\
Opportunity to do more & Receiving acknowledgments \\
Racism & Need for major results \\
Limited education & Revenue generation \\
Lack of good example & Use of experience, knowledge, skills \\
Unequal payments & Perennial dream realisation \\
Division of the profession & Realisation of economic goals \\
Lack of childcare & Stages of the life cycle \\
Discrimination & Feeling of personal values \\
The need for security & Need for dominance \\
\hline
\end{tabular}

Source: Fielden and Davidson (2005, p.266)

'Push' factors have greater impact on female entrepreneurs in deciding the type of business they want to establish. 'Pull' factors are more related with motivators to establish a personal business.

\subsection{Management skills}

Management skills and approaches have also been researched (Buttner, 2001; Gardiner and Tiggemann, 1999). Female entrepreneurs, before they start their businesses, need to evaluate their managerial skills which impact the success or failure of the enterprise. In research by Hisrich et al. (2006), when women were asked to evaluate their skills in several business areas, they rated themselves least capable in finance: $60 \%$ evaluated themselves as having poor or fair skills in this area; only $35 \%$ felt their finance skills were good or very good and none considered them excellent. The confidence of female entrepreneurs in human resource management was higher: $73 \%$ considered themselves good, very good or excellent in this area, while just $25 \%$ considered their skills to be fair or poor. Hisrich and Brush (1986) concluded that the majority of female entrepreneurs were weak in financial management; had average skills in marketing and operations and generating ideas/innovative products and establishing relations with people were their strongest skills (see Table 3).

These skills led the authors (Hisrich and Brush, 1986) to the following conclusions:

- Having weak skills in finance, marketing, planning and operations could present problems for the future growth of the business. As the business develops further, female entrepreneurs need to be able to balance expansion and sales growth and capital needs.

- Average skills in marketing and operations may not always be obstacles depending on the nature of the business. Since female entrepreneurs typically operate in the services sector, marketing skills can be outsourced. If the business is in the manufacturing sector or construction sector, these skills may need to be more developed. 
- Female entrepreneurs have strong managerial skills in areas dealing with relations with people and generating ideas. Good skills in dealing with people are very important for the culture of the company and relating with customers. Female entrepreneurs seem to be more tolerant and show more respect for human issues of the business, which makes them more sensitive and more prepared in dealing with problems than men. Good skills in generating ideas are important for all female entrepreneurs as it enables them to be more competitive in the market.

Table 3 Self-assessment of managerial skills of female entrepreneurs

\begin{tabular}{|c|c|c|c|c|c|c|}
\hline Managerial skill & Weak & Bad & Good & $\begin{array}{l}\text { Very } \\
\text { good }\end{array}$ & Excellent & $\begin{array}{c}\text { No } \\
\text { answer }\end{array}$ \\
\hline $\begin{array}{l}\text { Finance, ensuring capital, } \\
\text { forecasting, budgeting }\end{array}$ & 15 & 32 & 27 & 15 & 6 & 4 \\
\hline $\begin{array}{l}\text { Relationships with people - } \\
\text { management, development and } \\
\text { training }\end{array}$ & 2 & 10 & 28 & 33 & 27 & 0 \\
\hline $\begin{array}{l}\text { Marketing - sales, market } \\
\text { research, promotion }\end{array}$ & 6 & 20 & 20 & 33 & 22 & 0 \\
\hline $\begin{array}{l}\text { Generating ideas/innovative } \\
\text { products }\end{array}$ & 3 & 10 & 26 & 27 & 33 & 1 \\
\hline $\begin{array}{l}\text { Business activities - inventory, } \\
\text { production, daily activities }\end{array}$ & 3 & 18 & 32 & 30 & 17 & 0 \\
\hline $\begin{array}{l}\text { Planning and organisation - } \\
\text { strategy, organisational } \\
\text { structure, policies }\end{array}$ & 4 & 15 & 29 & 29 & 23 & 0 \\
\hline
\end{tabular}

Source: Hisrich and Brush (1986, p.32)

\section{Female entrepreneurs in ALMAKOS countries}

\subsection{Albania, Macedonia and Kosovo - some introductory notes}

Albania, Macedonia and Kosovo are small countries located in South-Eastern Europe, respectively in the Central Balkan Peninsula with Macedonia and Kosovo being successor states of the former Yugoslavia.

Albania declared its independence in 28 November 1912, which was recognised by the conference of London on 29 July 1913. It covers $28,750 \mathrm{~km}^{2}$ (11,101 square miles), bordering the Adriatic Sea to the west, the Ionian Sea to the southwest, Greece to the south and southeast, Macedonia to the east, Kosovo to the northeast and Montenegro to the northwest. The capital is Tirana, the largest city of Albania, inhabited by around $25 \%$ of the total population. According to the last Population and Housing Census, realised in 2011, the total population of Albania is 2,821,977. Albanians are divided into two dialect groups: Gheg and Tosk. Gheg is widespread in the north, while Tosk in the south (see Dana, 2010). In Albania, three national minorities (Greeks, Macedonians and Montenegrins) and two cultural minorities (Aromanians and Romani people) are present. The population of Albania consists of: Albanians 2,312,356 (83\%), Greeks 24,243 (1\%) and other ethnicities. The religious affiliation is: $57 \%$ Muslims, $14 \%$ undeclared, $10 \%$ 
Catholics, 7\% Orthodox and other (INSTAT, 2012; CIA World Factbook, 2012; UN, 2011). Albania is a member of the UN and NATO. The GDP (PPP) of Albania in 2012 was $\$ 29.86$ billion or $\$ 9.600$ per capita, a 3.5\% growth rate over 2011 (INSTAT, 2012).

Macedonia declared its independence on September 8, 1991 and became a member of the United Nations became on 8 April 1993 under the provisional reference of the Former Yugoslav Republic of Macedonia - FYROM (United Nations, 1993). It covers $25,713 \mathrm{~km}^{2}$ (9,928 square miles), bordering Albania, Kosovo, Serbia, Bulgaria and Greece. The capital is Skopje, the largest city of Macedonia, inhabited by $30 \%$ of the population. Based on the data from the last Census of Population, Macedonia has $2,022,547$ inhabitants. The ethnic groups, based in the country consist of: Macedonians, 1,297,981 (64\%); Albanians, 509,083 (25\%); Turks, 77,959 (4\%); Romani, 53,879 (3\%) and Serbs, 35,939 (2\%). The gross domestic product (GDP) in 2011 was 461,730 million denars (the currency of Macedonia), an increase of 6.4\% over 2010 (State Statistical Office of Republic of Macedonia, 2012; Dana, 1998).

Figure 3 The Almakos countries

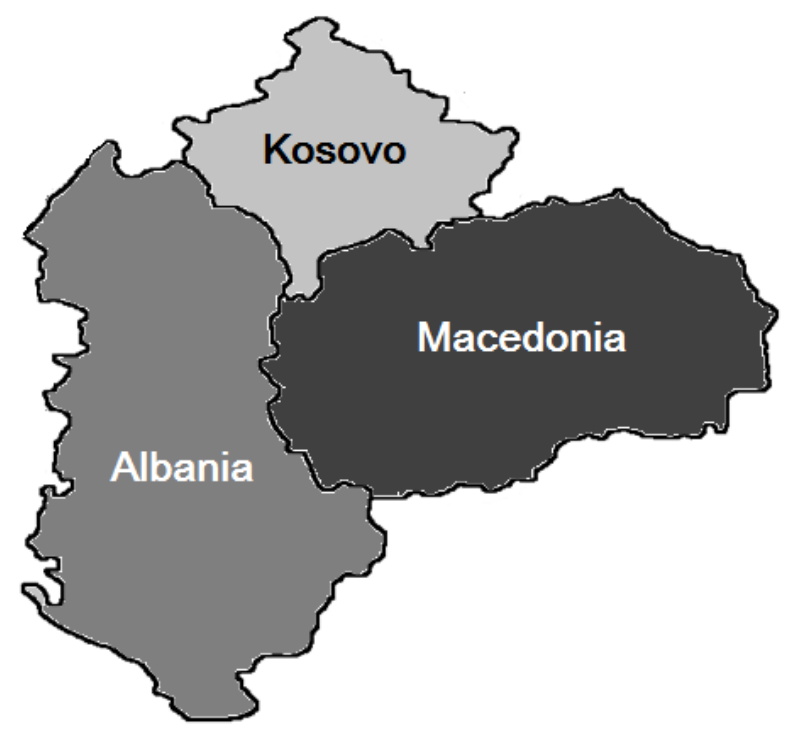

Kosovo is the newest country in Europe covering 10,908 km2 (9,928 square miles), bordering Albania and Macedonia to the south, Serbia to the north and east and Montenegro to the west. The capital is Prishtina, the largest city of Kosovo, inhabited by more than $15 \%$ of the total population. Kosovo declared its independence from Serbia 17 February 2008. Within the EU, 23 of 28 members have recognised Kosovo as an independent and sovereign. Serbia still refuses to recognise Kosovo's independence. Even that Kosovo is only partially recognised, it became a member of the International Monetary Fund (IMF), World Bank, European Bank for Reconstruction and Development, Council of Europe Development Bank, Regional Cooperation Council, International Road and Transport Union (IRU) and Venice Commission (Sinani, 2013). According to the 2011 census (ASK, 2012), there are 1,739,825 inhabitants. The population of Kosovo, according to ethnic group, consists of: Albanians, 1,616,869 
(93\%); Bosnians, 27,533 (2\%), Serbs, 25,532 (2\%); Turks, 18,738 (1\%); and Ashkali 15,436 (1\%). The GDP of Kosovo in 2012 was 6.95 billion \$ (World Bank, 2014).

\subsection{Current situation of female entrepreneurship}

Unfortunately there is a lack of official data with respect to female entrepreneurs but the global entrepreneurship monitor (GEM) provides some information about women entrepreneurs across different countries. Sarfaraz and Faghih (2011, p.52) noted that "GEM's contribution to providing consistent cross-country information and measurement of women's entrepreneurial activity are useful tools to identify entrepreneurial dimensions and rank different countries in this field as well". The lack of official information about women entrepreneurs does present an obstacle to research, since a "base set of measures cannot be shown to decision-makers" [Hontz and Rotanu, (2010), p.8].

Based on the data from the GEM Reports, according to the TEA index for women, it can be concluded that women from Montenegro, Croatia, Serbia, Bosnia and Herzegovina and Greece are more active in efforts to establish or manage a business (Figure 4). The TEA index for Macedonia, Romania, Slovenia and Turkey is around $3 \%$. In these reports, unfortunately there is no data about Albania, Kosovo and Bulgaria (Kelley et al., 2011; Allen et al., 2008). Studies have been done on entrepreneurship in Albania (Ramadani and Dana, 2013; Dana, 1996, 2010), Kosovo (Gashi and Ramadani, 2013) and Bulgaria (Ramadani and Dana, 2013; Dana, 1999, 2010).

Figure 4 Tea index for female entrepreneurs in the region

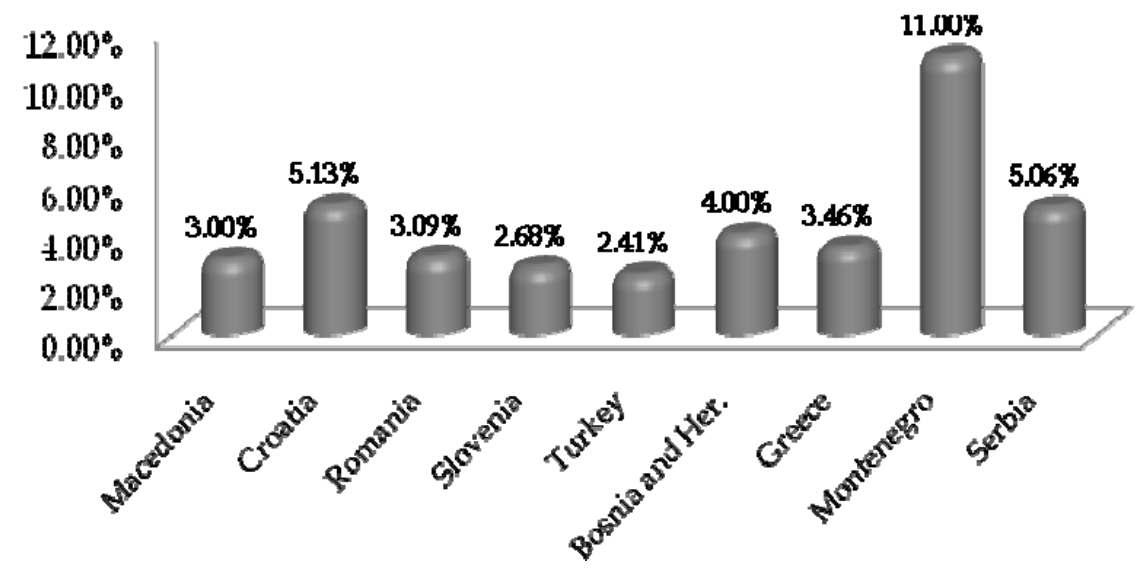

Source: According to Kelley et al. (2011, p.19) and Allen et al. (2008, p.12)

The research results of Sabarwal and Terrell (2008), indicated in Figure 5, show that the number of female entrepreneurs in Macedonia (around 18\%) is higher than that of Albania (around 13\%), but is lower than that of Slovenia (around 32\%), Croatia (around $20 \%$ ), Bosnia and Herzegovina (around 26\%), Serbia (around 26\%), Romania (around $28 \%$ ) and Bulgaria (around 36\%). In Kosovo, the number of women-owned businesses is around $10 \%{ }^{1}$. 
Figure 5 Share of female entrepreneurs by country

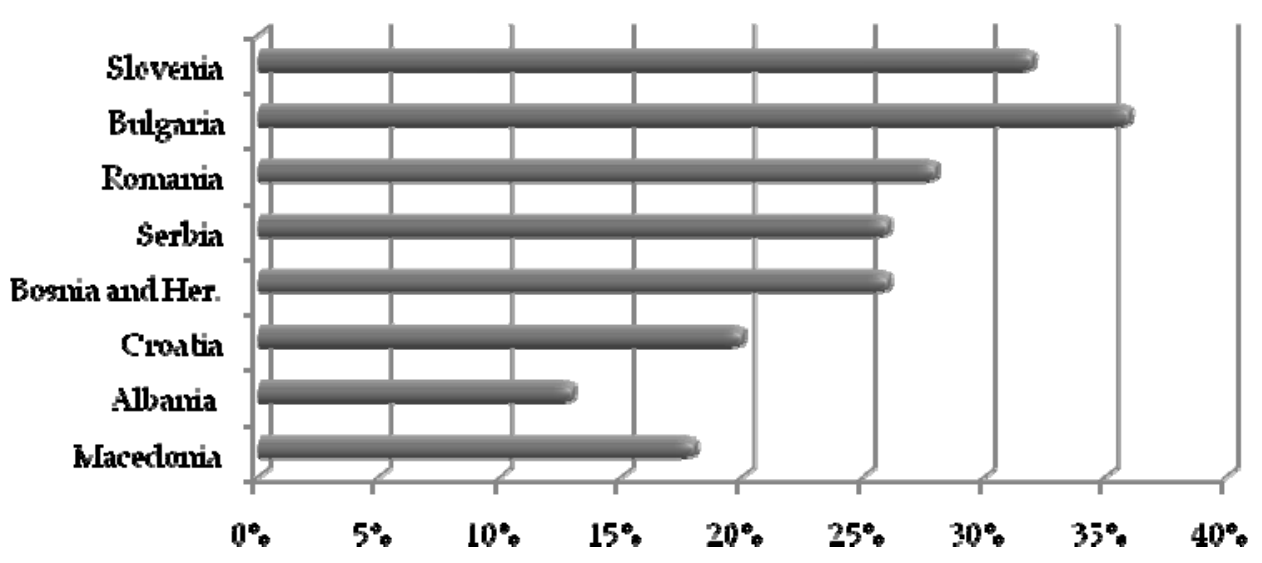

Source: Based on Sabarwal and Terrell (2008, p.44)

While female entrepreneurship in Albania was perceived as being almost impossible in the past, today women still face some difficulties in some business categories they might be involved. Imeraj and Gruda (2013) looked at 62 female entrepreneurs mainly in embroidery products and trading firms. The Albanian state statistical office has identified that $80 \%$ of female entrepreneurs' businesses are classified as small ones since the large and medium size firms are mainly owned by men. However, even through small businesses, women still offer quality products and services and support their family (Imeraj and Gruda, 2013). Strong motivations for women to start their own businesses are economic independence, obtaining personal income which is considered as a direct contribution to the family and create a feeling of equality between partners. The government as well as other national and especially many international organisations after 1990 have taken the initiative to support women in their entrepreneurial activities. In 1992 the government under the supervision of the Council of Ministries established the Women Department, nowadays known as 'Women and Family Committee'. This department encourages women participation in all different spheres of life through the development of social policies, improvement of legislation and collaboration with the local government (Hafizi, 2002; Bezhani, 2001). USAID has been a major player in providing money, strategy and plans for women development. Other organisations such as SNV Netherland Development Organization and the European Commission through PHARE programs offer financial support for projects of women NGO's; the German GTZ (now GIZ) has also provided training to 192 female entrepreneurs (Imeraj and Gruda, 2013).

In Macedonia, the Association of Women Organizations and some NGOs have an active policy to activate and involve women in economic and political life. Nevertheless, despite women's available human potential and capabilities for successful development of women entrepreneurship, strong governmental support is indispensable. While the Republic of Macedonia is a long way from adopting government support for women entrepreneurs, the Association of Women Entrepreneurs APNA and NIZA in Skopje have made a step forward in this. By providing material or immaterial governmental support, women can find their place in the Macedonian economy (Ramadani et al., 2013; Tašaminova, 2012). 
Female entrepreneurial activities are focused on fostering and promoting economic sustainability in Kosovo, as in other neighbouring countries. Since women often work in an unofficial and unregistered capacity, it is difficult to understand their role in the economy. From the data of the State Statistical Office (SOK), 54,412 business entities are registered in Kosovo, 31,220 of which are enterprises and 23,192 individual businesses. Out of this total number, only 3,301 businesses are owned by women [SOK, (2013), p.18]. This indicates that there is a big gap between men and women in ownership of business. In 2006 SHE-ERA, Kosovo's first NGO dedicated to female entrepreneurship surveyed 1,450 female entrepreneurs who run formal and informal businesses from the Albanian, Serbian, Bosnian and Turkish communities in Kosovo. The results indicated that $35 \%$ operate an informal business. $96 \%$ of the women running informal businesses indicated that economic legislation was not an obstacle, as their business was not registered. $77 \%$ of the women stated that they spend over eight hours per day in their business despite also having family obligations. The survey also found that entrepreneurial women in Kosovo lacked professional preparation and training for managing a successful business ${ }^{2}$.

However despite these conditions, a movement for the improvement and development of female entrepreneurship is occurring. In October 2010, the First International Conference of Women Entrepreneurs was held in Kosovo with 170 participants from the business community, state agencies, financial institutions, international and national organisations, prominent women entrepreneurs as well as representatives from national businesswomen associations from more than 13 countries from around the world attending. The conference provided a platform for the exchange of experiences and practices for the further advancement of female entrepreneurs' networks in the region ${ }^{3}$. SHE-ERA as an NGO's was established to empower women in the business sector by providing them with a number of business development services such as counselling in market research strategies, business plan training and assistance with fundraising. Since its creation, it has engaged in many projects and activities in order to increase the awareness of female entrepreneurship in Kosovo. In addition, SHE-ERA has created an online information database for female-owned businesses, which includes an e-market to promote women's business products ${ }^{4}$.

\subsection{Characteristics of female entrepreneurs}

As was previously noted, the characteristics of female entrepreneurs in ALMAKOS countries are identified through surveys conducted during January through March 2014 (Macedonia) and May through June 2014 (Albania and Kosovo). Female entrepreneurs were asked several general questions about the size of business they run, revenues realised and their family status to get a more complete profile of women as entrepreneurs in these countries. The results indicate that the typical female entrepreneur has a university education, manages a micro enterprise, is married and has one or more children. The women become managers prior to their 30th birthday and are present in the business world for 10 to 15 years. They are motivated to start a business due to the possibility to realise substantial profit, the desire to work exclusively for themselves on their own and the desire and need to realise significant achievements throughout the career. Furthermore, female entrepreneurs devote more than ten hours a day to their 
business. Knowledge and education, perseverance, persistence and confidence in the business world they consider to be the main reasons for achieving success in their entrepreneurial activities. Management capabilities that a woman entrepreneur in these countries possesses include: the ability to achieve solid communication with individuals, to generate and realise ideas and formulate goals, plans and policies and successfully implement. Each woman entrepreneur faced numerous problems in starting and managing their business such as establishment of balance between work and family, lack of time to enhance their capabilities through training, etc.

\subsubsection{Profile of female entrepreneurs}

The research results indicate that the majority of female entrepreneurs in ALMAKOS countries own and manage micro enterprises (1 to 9 employees): $44 \%$ of women run micro businesses, $36 \%$ small businesses, $14 \%$ medium businesses, while only $6 \%$ run large businesses with more than 250 employees. $72 \%$ of the women entrepreneurs were married or engaged and $78 \%$ have one or more children. Only $28 \%$ of respondents said they are not married or engaged, while $12 \%$ stated that they have no children. With respect to presence in the business world, $42 \%$ of female entrepreneurs have been active for three to six years, $28 \%$ between six and ten years, while $14 \%$ have 10 to 15 years of experience. Around $16 \%$ of female entrepreneurs had more than 15 years of business experience and none had less than two years. $36 \%$ of the businesses generate revenues above $25,000 €, 36 \%$ generate below $10,000 €, 22 \%$ generate between $10,000 €$ and $15,000 €, 14 \%$ generate between $15,000 €$ to $20,000 €$ and only $2 \%$ of the businesses had a monthly income between $20,000 €$ and $25,000 €$.

The women entrepreneurs in ALMAKOS countries started managing a business between 25 and 35 years of age. 37\% of the respondents answered that they began their own business at 25 and 30 years, $45 \%$ between 31 and 35 years, $7 \%$ started their business below the age of 25 and $11 \%$ over 35 years. Female entrepreneurs in Kosovo were younger than those from Albania and Macedonia when they started their businesses.

With regard to the level of education, the majority of female entrepreneurs have obtained higher education degrees. $73 \%$ of women surveyed had a university degree, $19 \%$ had postgraduate studies, only $8 \%$ had secondary education and only $1 \%$ had primary education. Female entrepreneurs from Albania are slightly better educated in comparison with those from Macedonia and Kosovo.

Within the questionnaire, an important question was related to the motives of the women to launch their own businesses. $63 \%$ of respondents stated that the main motive is freedom and control in decision-making processes, followed by $59 \%$ of women motivated by profit; desire for achievement is the most important for $48 \%$ of women, while $37 \%$ of female entrepreneurs consider the opportunity to work exclusively for themselves as the main motive for starting an entrepreneurial career. Social status was a less important motive, indicated $21 \%$ of women. 'Control and freedom' as a motive dominated in Albania and Macedonia by $68 \%$, respectively $64 \%$ of surveyed female entrepreneurs, while 'profit' was for female entrepreneurs from Kosovo. 'Social status' was ranked as a less important motive for each of the countries' women entrepreneurs (see Table 4). 
Table 4 Characteristics of surveyed female entrepreneurs in ALMAKOS (\%)

\begin{tabular}{|c|c|c|c|c|}
\hline Characteristics & Albania & Macedonia & Kosovo & $\begin{array}{c}\text { ALMAKOS } \\
\text { (average) }\end{array}$ \\
\hline \multicolumn{5}{|l|}{ Age } \\
\hline Under 25 & 8 & 8 & 14 & 7 \\
\hline 25 to 30 & 36 & 42 & 48 & 37 \\
\hline 31 to 35 & 44 & 42 & 34 & 45 \\
\hline Over 35 & 12 & 8 & 14 & 11 \\
\hline \multicolumn{5}{|l|}{ Education } \\
\hline Primary & 0 & 0 & 2 & 1 \\
\hline Secondary & 4 & 8 & 12 & 8 \\
\hline University & 68 & 72 & 78 & 73 \\
\hline Post-graduate & 28 & 20 & 8 & 19 \\
\hline \multicolumn{5}{|l|}{ Motives } \\
\hline Profit & 54 & 62 & 60 & 59 \\
\hline Working for themselves & 30 & 38 & 42 & 37 \\
\hline Control and freedom & 68 & 64 & 58 & 63 \\
\hline Social status & 24 & 18 & 22 & 21 \\
\hline Self-achievement & 42 & 50 & 52 & 48 \\
\hline Other & 10 & 8 & 6 & 8 \\
\hline \multicolumn{5}{|l|}{ Sectors } \\
\hline Agriculture & 4 & 2 & 4 & 3 \\
\hline Trade & 14 & 18 & 22 & 18 \\
\hline Manufacturing & 14 & 16 & 8 & 13 \\
\hline Construction & 12 & 14 & 12 & 13 \\
\hline Services & 54 & 46 & 50 & 50 \\
\hline Other & 2 & 4 & 4 & 3 \\
\hline
\end{tabular}

Source: Survey results

Female entrepreneurs in ALMAKOS countries run businesses in various business sectors. $50 \%$ operate in the service sector, $18 \%$ in trade, $13 \%$ in manufacturing, $13 \%$ in construction and $3 \%$ in the agricultural sector. If we analyse separately the sector orientations between ALMAKOS countries, Albanian female entrepreneurs are more oriented in services, Kosovo's female entrepreneurs in trade and Macedonian female entrepreneurs in manufacturing.

\subsubsection{Hours dedicated to the business}

Being an entrepreneur requires a certain way of life and a particular lifestyle. Most of female entrepreneurs spend a significant share of their time working. According to the survey results (Figure 6), 53\% of the respondents spend 10 hours and more a day working and $34 \%$ work between eight and ten hours a day. Only $13 \%$ of women spend five to eight hours a day working on business activities and none of the women spend less than four hours. 
Figure 6 Hours dedicated to the business

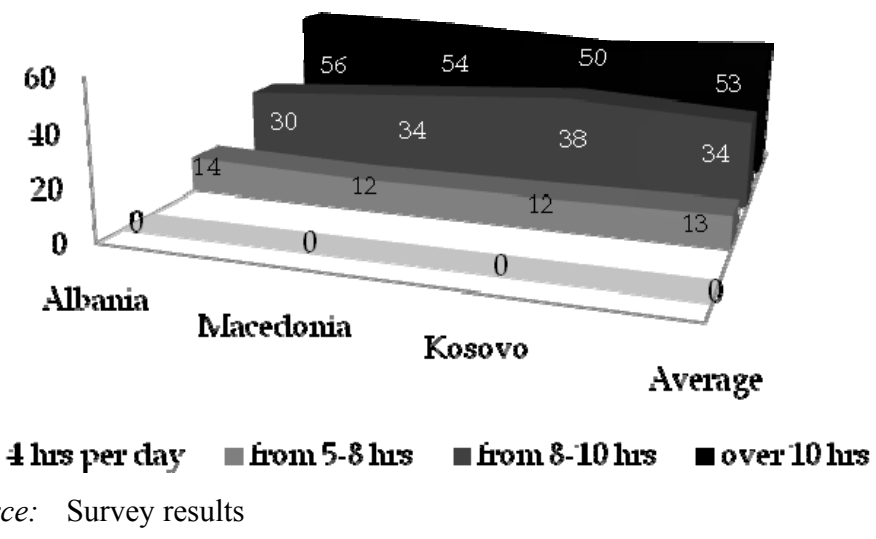

\subsubsection{Main problems and challenges faced by female entrepreneurs}

In business, every entrepreneur faces many problems and obstacles. The main problems that women entrepreneurs faced were the difficulties in establishing balance between family and work (see Figure 7). 61\% of the surveyed women have set this problem as number one. $29 \%$ of the women said they faced other problems than the ones we listed. Other problems include: finance (33\%), insufficient time in order to enhance their skills through various training sessions $(25 \%)$ and creating high-quality networks that would enable them to successfully run a business (33\%). Collecting quality information was indicated by $13 \%$ of women in ALMAKOS countries and lack of confidence by $4 \%$ of the surveyed women entrepreneurs.

Figure 7 Main problems faced by female entrepreneurs (\%)

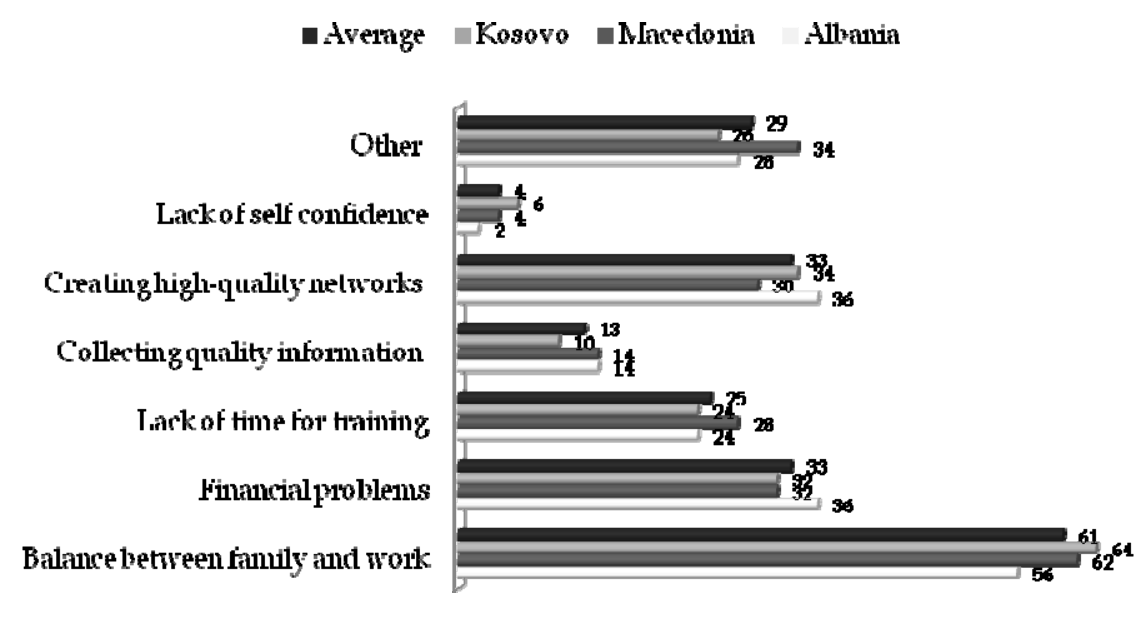

Source: Survey results 


\subsubsection{Management skills and factors affecting the success of female entrepreneurs}

Figure 8 indicates the importance of management skills required to achieve a success, as perceived by the surveyed female entrepreneurs. $77 \%$ of the female entrepreneurs reported that they are able to establish qualitative relationships with clients. $46 \%$ of the women believe that they are able to formulate goals, policies and plans and implement them. $41 \%$ feel they have the ability to manage the finances of their business and ability to generate and implement ideas. $27 \%$ believe that they are able to manage marketing activities, while $19 \%$ feel they have the ability to manage inventory and to execute specific business strategies.

Figure 8 Management skills of female entrepreneurs

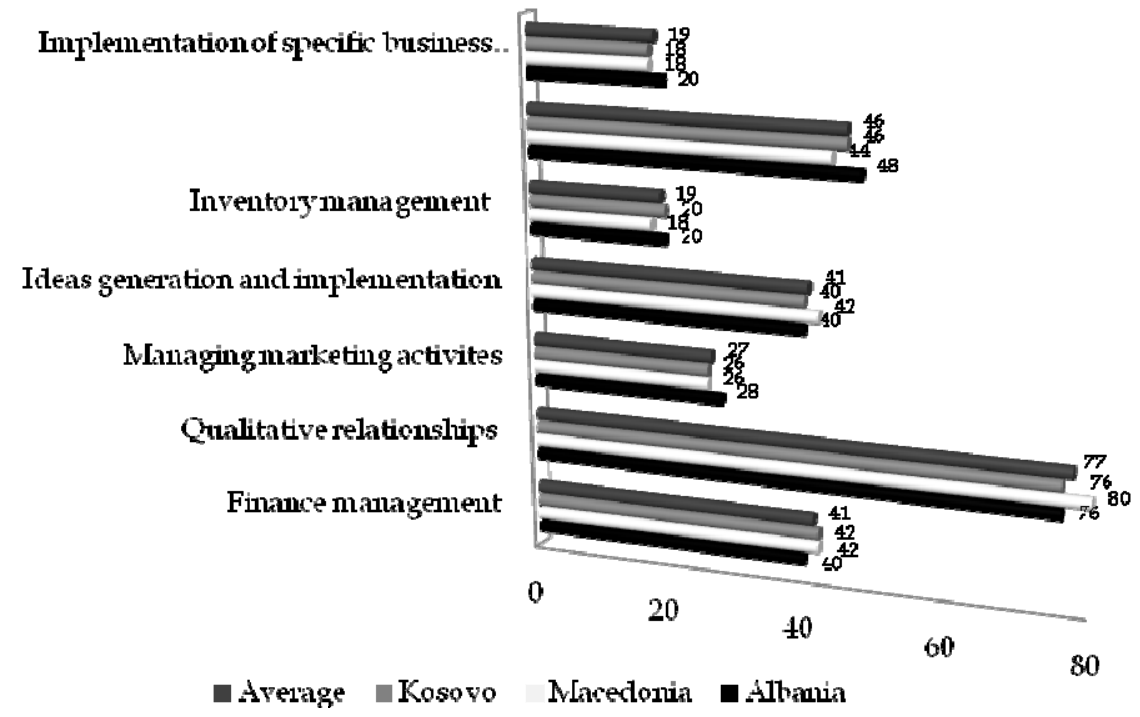

Source: Survey results

Figure 9 Factors affecting the success of female entrepreneurs and their businesses

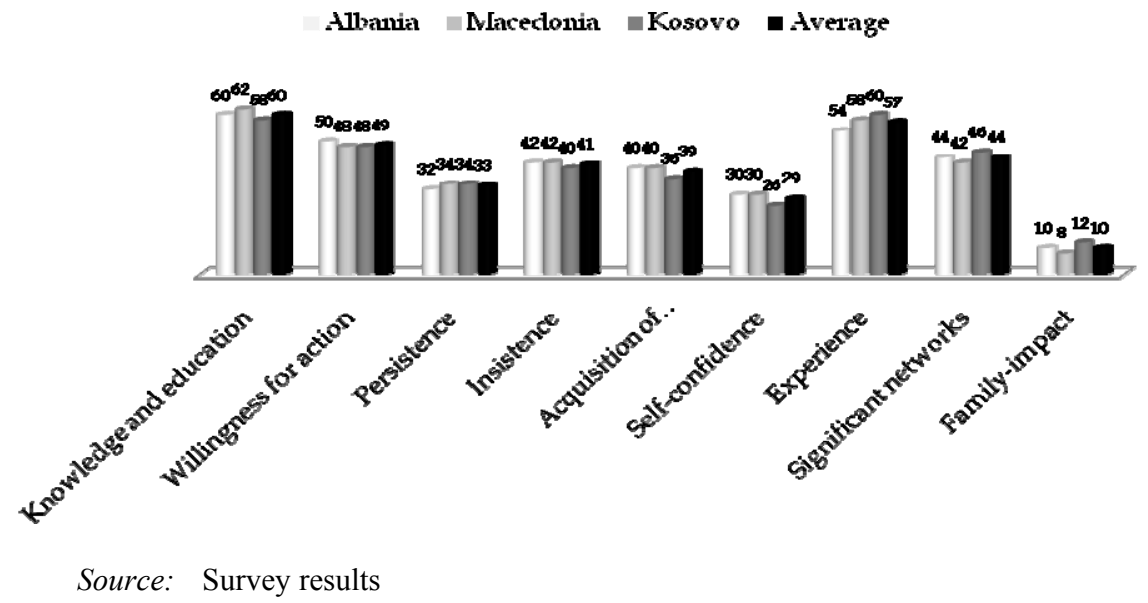


As it is shown in Figure 9, $60 \%$ of female entrepreneurs believe that one of the most important factors to achieve success in business is the knowledge and the education that they possess. This is followed by experience they gained by operating in the business sector $(57 \%)$. The following factors are also considered important: willingness to take certain actions in order to manage properly the business (49\%), significant networks (44\%), taking calculated risks (39\%), persistence (33\%), self-confidence $(29 \%)$ and family-impact (10\%).

\section{Summary, conclusions and recommendations}

Although there is limited qualitative, quantitative data available, women are increasingly an important part of the economic and social life in transitional economies (Ramadani et al., 2013; Hisrich et al., 2006; Aidis et al., 2007). According to survey responses obtained, the main factor that encourages women to start entrepreneurial careers is the freedom to make important business decisions. Profit and money are another motive as well as the desire to attain significant achievements in their careers. In order to be free and make significant achievements in their work, women must overcome many problems. Major obstacles faced as entrepreneurs are related to difficulties in establishing the balance between family obligations and work commitments. Bearing in mind that they dedicate most of their available time to their business, they also may face problems in fulfilment of their responsibilities as both wives and mothers. To overcome these problems, women need to posses several qualities and skills. Successful business requires relevant education, relevant knowledge and skills, as well as the commitment to be proactive rather than reactive. Experience, persistence, perseverance and self-confidence are also considered important characteristics for the successful development of business.

Entrepreneurship is important for economic and social development. Policymakers should be focused on development of entrepreneurship. Female entrepreneurs are a very important untapped resource within the business sector. To support their commitments, female entrepreneurs need appropriate assistance in both starting and growing a business. Several recommendations in the development of female entrepreneurship in ALMAKOS countries are presented below:

- Supporting micro-enterprises. Our research indicates that $44 \%$ of the surveyed female entrepreneurs in the ALMAKOS countries run micro-enterprises. These businesses have encountered problems due to their size and limited resources. Starting up new businesses and obtaining necessary capital is a significant challenge. Women entrepreneurs often are struggling to keep pace with obtaining information on new ICT developments and trends. It is important to provide assistance and support to such businesses so they can meet these challenges and benefit from using various financial instruments. Simplified administrative procedures and assistance in creating female entrepreneurs networks would also be beneficial.

- Financial support. Obtaining debt and equity capital is also a major problem faced by female entrepreneurs. Investors and banks are often reluctant to finance start-up businesses run by women, since they involve a certain degree of risk. Programs that will directly improve the financial environment and provide a variety of financial instruments and impetuses that will assist women in running their businesses are needed. 
- Training programs. It is important to stimulate the desire in individuals for an entrepreneurial career as entrepreneurs provide the basis for building competitiveness and innovation in the country. Women should be adequately educated and encouraged to start their own business and build entrepreneurial careers. Such support, especially in the field of female entrepreneurship is provided by the European Network of Mentors for Female Entrepreneurs that is already operating in Macedonia. This project aims to establish a national network of mentors for female entrepreneurs and provide assistance in meeting challenges faced by women in the first years of their businesses' operation. It also aims to support the development of women's entrepreneurship in the country, taking into account the specific features of the businesses run by women.

- Creating a database of female entrepreneurs. Establishing a database will provide the basis for policy creation and help promote female entrepreneurship. Gender sensitive policies aimed at improving women's economic status are needed as these will help provide strong social and educational programs and training sessions in the ALMAKOS region.

\section{References}

Aidis, R. (2003) 'Female small and medium-sized enterprise ownership in Lithuania: a comparison', Journal of Baltic Studies, Vol. 14, No. 3, pp.332-353.

Aidis, R., Welter, F., Smallbone, D. and Isakova, N. (2007) 'Female entrepreneurship in transition economies: the case of Lithuania and Ukraine', Feminist Economics, Vol. 13, No. 2, pp.157-183.

Allen, E.I, Elam, A., Langowitz, N. and Dean, M. (2008) 2007 Report on Women Entrepreneurship, Babson College, MA.

ASK (2012) Census 2011 [online] http://ask.rks-gov.net/publikimet/cat_view/8popullsia?orderby=dmdate_published (accessed 31 August 2014).

Baker, T., Aldrich, H.E. and Liou, N. (1997) 'Invisible entrepreneurs: the neglect of women business owners by mass media and scholarly journals in the United States', Entrepreneurship and Regional Development, Vol. 9, No. 3, pp.221-238.

Baughn, C., Chua, B.L. and Neupert, K. (2006) 'The normative context for women's participation in entrepreneurship: a multi-country study', Entrepreneurship: Theory and Practice, Vol. 30, No. 5, pp.687-708.

Bennett, R. and Dann, S. (2000) 'The changing experience of Australian female entrepreneurs', Gender, Work and Organisation, Vol. 7, No. 2, pp.75-83.

Berg, N.G. (1997) 'Gender, place and entrepreneurship', Entrepreneurship and Regional Development, Vol. 9, No. 3, pp.259-268.

Bezhani, M. (2001) Women Entrepreneurs in Albania, Series on Women's Entrepreneurship Development and Gender in Enterprises - WEDGE, SEED Working Paper No. 21.

Box, T.W., Beisel, J.L. and Watts, L.R. (1995) 'Thai entrepreneurs: an empirical investigation of individual differences, background and scanning behaviour', Academy of Entrepreneurship Journal, Vol. 1, No. 1, pp.18-25.

Brush, C. (1992) 'Research on women business owners: past trends, a new perspective and future directions', Entrepreneurship Theory and Practice, Vol. 16, No. 4, pp.5-30.

Brush, G.C., Carter, M.N., Gatewood, J.E., Greene, G.P. and Hart, M.M. (2006) Growth-Oriented Women Entrepreneurs and their Businesses: A Global Research Perspective, Edward Elgar, Cheltenham. 
Buttner, E.H. (2001) 'Examining female entrepreneurs' management style: an application of a relational frame', Journal of Business Ethics, February, Vol. 29, No. 3, pp.253-269.

Buttner, E.H. and Moore, D.P. (1997) 'Women's organizational exodus to entrepreneurship: self-reported motivations and correlates with success', Journal of Small Business Management, Vol. 35, No. 1, pp.34-46.

Byrne, M.J. and Fayolle, A. (2013) 'Necessity entrepreneurs in France: women and business support services', in Kariv, D. (Ed.): Female Entrepreneurship and the New Venture Creation: An International Overview, Routledge, New York and London.

Carter, S. and Marlow, S. (2007) 'Female entrepreneurship: theoretical perspectives and empirical evidence', in Carter, M.N, Henry, C., O'Cinneide, B. and Johnston, K. (Eds.): Female Entrepreneurship: Implications for Education, Training and Policy, Routledge, Abington.

CIA World Factbook (2012) Albania: People, Central Intelligence Agency, US.

Dana, L-P. (1996) 'Albania in the twilight zone: the perseritje model and its impact on small business', Journal of Small Business Management, Vol. 34, No. 1, pp.64-70

Dana, L-P. (1997) 'The origins of self-employment in ethnocultural communities: distinguishing between orthodox entrepreneurship and reactionary enterprise', Canadian Journal of Administrative Sciences, Vol. 14, No. 1, pp.52-68.

Dana, L-P. (1998) 'Waiting for direction in the Former Yougoslav Republic of Macedonia (FYROM)', Journal of Small Business Mangement, Vol. 36, No. 2, pp.62-67

Dana, L-P. (1999) 'Bulgaria at the crossroads of entrepreneurship', Journal of Euromarketing, Vol. 8, No. 4, pp.27-50.

Dana, L-P. (2010) When Economies Change Hands: A Survey of Entrepreneurship in the Emerging Markets of Europe from the Balkans to the Baltic States, Routledge, New York and Oxford.

Dombrovsky, V. and Ieva, U. (2005) Entrepreneurship in Latvia, Telia Sonera Institute Discussion Paper No. 2, Stockholm School of Economics in Riga, Latvia.

Duchénaut, B. (1997) Women Entrepreneurs in SMEs, Euro PME, Rennes.

Eurochambres (2004) Women in Business and in Decision-Making: A Survey on Women Entrepreneurs, Eurochambres, Brussesls.

Fielden, S.L. and Davidson, J.M. (2005) 'The way forward for women small business owners', in Fielden, S.L. and Davidson, J.M. (Eds.): International Handbook of Women and Small Business Entrepreneurship, Edward Elgar Publishing Limited, Cheltenham.

Franco, A. and Winqvist, K. (2002) The Entrepreneurial Gap Between Women and Men, Eurostat, Brussels.

Gardiner, M. and Tiggemann, M. (1999) 'Gender differences in leadership style, job stress and mental health in male-and female-dominated industries', Journal of Occupational and Organisational Pychology, Vol. 72, No. 3, pp.301-315.

Gashi, G. and Ramadani, V. (2013) 'Family businesses in Republic of Kosovo: some general issues', in Ramadani, V. and Schneider, C.R. (Eds.): Entrepreneurship in the Balkans: Diversity, Support and Prospects, pp.91-115, Springer, Heidelberg.

Global Entrepreneurship Monitor (2004) Women and Entrepreneurship, Centre for Women's Leadership, Babson College, MA.

Gobagoba, M.R. and Littrell, M.A. (2003) 'Profiling micro apparel enterprises in Botswana: motivations, practices, challenges, and success', Clothing and Textiles Research Journal, Vol. 21, No. 3, pp.130-141.

Hafizi, M. (2002) 'Female entrepreneurship in Albania', Proceedings: International Symposium on Learning Management and Technology Development in the Information and Internet Age, University of Bologna.

Henry, C. and Johnston, K. (2007) 'Introduction', in Carter, M.N., Henry, C., O'Cinneide, B. and Johnston, K. (Eds.): Female Entrepreneurship: Implications for Education, Training and Policy, Routledge, Abington. 
Hisrich, D.R. (1984) 'The woman entrepreneur in the United States and Puerto Rico: a comparative study', Leadership and Organization Development Journal, Vol. 5, No. 5, pp.3-8.

Hisrich, D.R. (1986) 'The woman entrepreneur: a comparative analysis', Leadership and Organization Development Journal, Vol. 7, No. 2, pp.8-16.

Hisrich, D.R. and Brush, G.C. (1986) The Woman Entrepreneur: Starting, Financing and Managing a Successful New Business, Lexington Books, Massachusetts.

Hisrich, D.R. and Fan, Z. (1991) 'Women entrepreneurs in the people's Republic of China: an exploratory study', Journal of Managerial Psychology, Vol. 6, No. 3, pp.3-12

Hisrich, D.R. and Ozturk, S. (1999) 'Women entrepreneurs in a developing economy', Journal of Management Development, Vol. 18, No. 2, pp.114-124.

Hisrich, D.R., Bowser, K. and Smarsh, L.S. (2006) 'Women entrepreneurs in the Ukraine', Int. J. Entrepreneurship and Small Business, Vol. 3, No. 2, pp.207-221

Hisrich, D.R., Brush, C.G., Good, D. and DeSouza, G. (1997) 'Performance in entrepreneurial ventures: does gender matter?', Frontiers of Entrepreneurship Research, Babson College, Massachusetts.

Hontz, E. and Rotanu, C. (2010) Women's Business Associations from Around the World: Central and Eastern Europe, Center for International Private Enterprise, Washington.

Hughes, K.D. (2003) 'Pushed or pulled: women's entry into self-employment and small business ownership', Gender, Work and Organization, Vol. 10, No. 4, pp.433-454.

Hughes, K.D. (2005) Female Enterprise in the New Economy, University of Toronto Press Incorporated, London.

Imeraj, E. and Gruda, S. (2013) 'Challenges of women entrepreneurs in Albania', Mediterranean Journal of Social Sciences, Vol. 14, No. 11, pp.467-471

INSTAT (2012) Population and Housing Census 2011, Institute of Statistics of Albania, Tirana.

Jones, K. (2000) 'Psychodynamics, gender and reactionary entrepreneurship in Metropolitan Sao Paulo, Brazil', Women in Management Review, Vol. 15, No. 4, pp.207-220.

Kariv, D. (2013) Female Entrepreneurship and the New Venture Creation, Routledge, New York and London.

Kelley, J.D., Brush, D.G., Greene, G.P. and Litovsky, Y. (2011) 2010 Report: Women Entrepreneurs Worldwide, Babson College, MA.

Kitching, B. and Woldie, A. (2004) 'Female entrepreneurs in transitional economies: a comparative study of businesswomen in Nigeria and China', Proceedings Hawaii International Conference on Business, Honolulu, Hawaii.

Maysami, C. and Goby, V.P. (1999) 'Female business owners in Singapore and elsewhere: a review of studies', Journal of Small Business Management, Vol. 37, No. 2, pp.96-105.

Minniti, M., Arenius, P. and Langowitz, N. (2005) 2004 Report on Women and Entrepreneurship: Global Entrepreneurship Monitor, The Center for Women's Leadership at Babson College, Wellesley.

OECD (2004) Women's Entrepreneurship: Issues and Policies, OECD Publishing, Paris.

Ramadani, V. and Dana, L-P. (2013) 'The state of entrepreneurship in the balkans: evidence from selected countries', in Ramadani, V. and Schneider, C.R. (Eds.): Entrepreneurship in the Balkans: Diversity, Support and Prospects, pp.217-250, Springer, Heidelberg.

Ramadani, V., Dana, L-P., Gerguri, S. and Tašaminova, T. (2013) 'Women entrepreneurs in the Republic of Macedonia: waiting for directions', Int. J. Entrepreneurship and Small Business, Vol. 19, No. 1, pp.95-121.

Reynolds, P.D. and White, S.B. (1997) The Entrepreneurial Process: Economic Growth, Men, Women and Minorities, Quorum Books, Westport.

Sabarwal, S. and Terrell, K. (2008) Does Gender Matter for Firm Performance? Evidence from Eastern Europe and Central Asia, World Bank, Washington. 
Sarfaraz, L. and Faghih, N. (2011) 'Women's entrepreneurship in Iran: a GEM based-data evidence', Journal of Global Entrepreneurship Research, Vol. 1, No. 1, pp.45-57

Shuklev, B. and Ramadani, V. (2012) Small Business and Entrepreneurship, South-East European University, Tetovo.

Sinani, N. (2013) Will the EBRD do the Right Thing for Kosovo, its Newest Member?, NewEurope [online] http://www.neurope.eu/kn/article/will-ebrd-do-right-thing-kosovo-its-newest-member (accessed 31 August 2014).

SOK (2013) Registered Businesses in Kosovo [online] https://ask.rks-gov.net/eng/ (accessed 5 September 2014).

State Statistical Office of Republic of Macedonia (2012) Macedonia in Figures, Government of Republic of Macedonia, Skopje.

Still, V.L. (2005) 'The constraints facing women entering small business entrepreneurship', in Fielden, S.L. and Davidson, J.M. (Ed.): International Handbook of Women and Small Business Entrepreneurship, Edward Elgar Publishing Limited, Cheltenham.

Tašaminova, T. (2012) Women Entrepreneurs in Macedonia: Situation, Problems and Perspectives, Master Thesis, South-East European University, Tetovo.

Taylor, R.S. and Newcomer, D.J. (2005) 'Characteristics of women small business owners', in Fielden, S.L. and Davidson, J.M. (Eds.): International Handbook of Women and Small Business Entrepreneurship, Edward Elgar Publishing Limited, Cheltenham.

UN (2011) World Directory of Minorities and Indigenous Peoples - Albania: Overview [online] http://www.refworld.org/docid/4954cdfela.html (accessed 31 August 2014).

United Nations (1993) Admission of the State whose Application is Contained in Document A/47/876-S/25147 to Membership in the United Nations [online] http://www.un.org/ documents/ga/res/47/a47r225.htm (accessed 22 November 2012).

Walker, E. and Brown, A. (2004) 'What success factors are important to small business owners?', International Small Business Journal, Vol. 22, No. 6, pp.577-594.

Welter, F. and Smallbone, D. (2010) 'The embeddedness of women's entrepreneurship in a transition context', in Brush, C., Bruin, A., Gatewood, E. and Henry, C. (Eds.): Women Entrepreneurs and the Global Environment for Growth: A Research Perspective, pp.96-117, Edward Elgar, Northampton.

Welter, F., Smallbone, D., Isakova, N., Aculai, E. and Schakirova, N. (2004) 'Female entrepreneurship in the Ukraine, Moldova and Uzbekistan: characteristics, barriers and enabling factors and policy issues', in UNECE (Ed.): Access to Financing and ICT: Women Entrepreneurs in the ECE Region, pp.93-52, United Nations, Geneva.

World Bank (2014) Kosovo [online] http://data.worldbank.org/country/kosovo (accessed 31 August 2014).

\section{Notes}

1 SHE-ERA [online] http://she-era.org/ sheera/eng/wp-content/uploads/2013/08/WOMENENTERPRENURS-IN-KOSOVO-ANALYSES.pdf.

2 SHE-ERA [online] http://she-era.org/ sheera/eng/wp-content/uploads/2013/08/WOMENENTERPRENURS-IN-KOSOVO-ANALYSES.pdf.

3 UNDP Kosovo [online] http://www.ks.undp.org/content/kosovo/en/home/ourwork/ womenempowerment/successstories/women-entrepreneurs-report-launched.

4 Community of women entrepreneurs [online] $\mathrm{http}: / /$ www.reformsnetwork.org/women/?p=1056. 